\title{
Solar Water Heating as a Potential Source for Inland Norway Energy Mix
}

\author{
Dejene Assefa Hagos, ${ }^{1,2}$ Alemayehu Gebremedhin, ${ }^{1}$ and Björn Zethraeus ${ }^{2}$ \\ ${ }^{1}$ Faculty of Technology, Economy and Management, Gjøvik University College, 2802 Gjøvik, Norway \\ ${ }^{2}$ Department of Building and Energy Technology, Linnaeus University, 35195 Våxjö, Sweden \\ Correspondence should be addressed to Dejene Assefa Hagos; dejene.hagos@hig.no
}

Received 30 April 2014; Revised 5 July 2014; Accepted 7 July 2014; Published 4 August 2014

Academic Editor: Jayanta Deb Mondol

Copyright (c) 2014 Dejene Assefa Hagos et al. This is an open access article distributed under the Creative Commons Attribution License, which permits unrestricted use, distribution, and reproduction in any medium, provided the original work is properly cited.

\begin{abstract}
The aim of this paper is to assess solar potential and investigate the possibility of using solar water heating for residential application in Inland Norway. Solar potential based on observation and satellite-derived data for four typical populous locations has been assessed and used to estimate energy yield using two types of solar collectors for a technoeconomic performance comparison. Based on the results, solar energy use for water heating is competitive and viable even in low solar potential areas. In this study it was shown that a typical tubular collector in Inland Norway could supply $62 \%$ of annual water heating energy demand for a single residential household, while glazed flat plates of the same size were able to supply $48 \%$. For a given energy demand in Inland Norway, tubular collectors are preferred to flat plate collectors for performance and cost reasons. This was shown by break-even capital cost for a series of collector specifications. Deployment of solar water heating in all detached dwellings in Inland could have the potential to save $182 \mathrm{GWh}$ of electrical energy, equivalent to a reduction of 15,690 tonnes of oil energy and $48.6 \mathrm{ktCO} \mathrm{emissions}$, and contributes greatly to Norway $67.5 \%$ renewable share target by 2020 .
\end{abstract}

\section{Introduction}

As the impact of fossil fuels on our precious environment is becoming more pronounced, all over the world, governments have started to implement multiple measures to increase the share of renewables in their existing fossil intensive energy systems, with these effectively emerging as political and economic issues. Within these, in 2007 the EU established the so-called 20-20-20 vision of a $20 \%$ emission reduction in reference to 1990 levels, a $20 \%$ increase in the share of renewables in the energy mix and a $20 \%$ reduction in energy consumption by 2020 [1]. In line with this, the long-term framework of EU renewable energy directives, which came into force in December 2011, has motivated the Norwegian government to set a target of increasing the share of renewables from $60 \%$ in 2005 to $67.5 \%$ by 2020 [2]. This could be accomplished by either increasing renewable energy production or increasing the share of renewables in energy consumption. The Norway-Sweden common tradable green certificate (TGC) market launched in January 2012 for 26 TWh new electricity generation cooperation is one key measure towards achieving the 2020 target [3]. On the other hand, the residential sector in Norway is energy-intensive and is a key sector to be focused on in terms of energy efficiency.

In the Nordic countries, the energy used in the building sector accounts for $33 \%$ of total energy use, of which residential buildings account for $67 \%$ and service buildings for $33 \%$ [4]. Space and water heating in the residential sector account for $60 \%$ and $13 \%$ of total energy use, respectively, while direct $\mathrm{CO}_{2}$ emission per capita amounted to 0.24 tonnes in 2009, much lower than other OECD European countries, 0.8 tonnes [4]. This is due to the insignificant share of oil use in the residential sector. In the Nordic countries in general, electricity is a highly used commodity, followed by commercial heating (district heating). Specifically in Norway, the heating sector is "monopolized" by electricity. Due to extensive development of hydropower and low electricity prices in the recent decades in Norway, the share of electric energy used for heating in households was quite significant. Energy use in households stands at electricity $77 \%$, biomass $18.5 \%$, and oil 4.5\% [2]. Based on Statistics Norway report [5], 
$65 \%$ of households' electric energy consumption was used for heating, of which $41 \%$ was used for space heating and $24 \%$ for water heating. Electric energy is high-quality energy and must be used for electricity-specific energy consumption or its value should be amplified (as in heat pumps). As opposed to this, using high-quality energy for low-quality energy production in direct electric heaters devalues the overall energy system efficiency. As of 2009, the share of households using heat pumps for space heating was only $18.5 \%$; this increases to $33 \%$ in detached houses [6]. With this consideration, $81.5 \%$ of the remaining households use direct electric space heating, which makes the energy efficiency much worse. Moreover, a low district heating share (6\%) [4] and heat pump deployment (18.5\%), together with $95.2 \%$ electricity generation from a single source (hydropower) [7], are impeding system integration and flexibility between the heating and electricity sectors in Norway. In this regard, implementing energy efficiency measures together with penetration of more renewable sources in the heating sector would help as a means to cut down electricity consumption and contribute greatly to the vision of increasing the share of renewable energy by 2020.

Solar energy is a free, inexhaustible, and environmentfriendly resource. Solar thermal energy for heating largely depends on solar energy availability and cost competitiveness. At the end of 2011, installed solar thermal capacity totaled $234.6 \mathrm{GW}_{\text {th }}$ globally, of which $60 \%$ was installed in China, $17 \%$ in Europe, and $7 \%$ in the USA [8]. More than $85 \%$ of the installations are for domestic water heating in single family houses. These installations globally contribute 20.9 million tons of saved oil energy per annum and a reduction in $\mathrm{CO}_{2}$ emissions of 64.1 million tonnes [8]. Chinese government policy for incentives is considered to be the main driver for significant penetration in China [9]. The Chinese government also plans to boost solar thermal installation from $152 \mathrm{GW}_{\text {th }}$ in 2011 to $560 \mathrm{GW}_{\text {th }}$ by 2020 [9]. On the other hand, high initial cost, a limited number of distributors, and public perceptions of aesthetics and reliability are a few reasons for the low market adoption in the USA [9].

Germany is the leading country in Europe with $10.73 \mathrm{GW}_{\text {th }}$ solar collector installed capacity, which corresponds to $131 \mathrm{~kW}_{\text {th }}$ per 1,000 inhabitants, followed by Austrai $\left(3.3 \mathrm{GW}_{\mathrm{th}}\right)$, Greece $\left(2.89 \mathrm{GW}_{\mathrm{th}}\right)$, and Italy $\left(2.09 \mathrm{GW}_{\mathrm{th}}\right)$, as of 2011 [8]. Germany alone constitutes $27 \%$ of the total installed capacity in Europe and greatly contributed to $17.96 \mathrm{MtCO}_{2}$ annual emission reduction in Europe and the 20\% worldwide solar collector market growth in the last decade [8]. Solar thermal deployment in Europe has resulted in multiple benefits. For example, during 2010, annual solar yield of 17.3 TWh contributes to $12 \mathrm{Mt}$ emission reduction, 2.6 billion $€$ turnover from the solar thermal market, and created new job opportunities for 33,500 persons [10]. Moreover, a large volume of the annual turnover was generated by small-scale local businesses engaged in selling, planning, installing, and servicing solar thermal systems. More than $97 \%$ of the total installed solar thermal systems in Europe have been used for domestic hot water production, and the remaining $3 \%$ are connected with large-scale district heating systems. Tax exemptions and deductions are the main policy tools for increased solar heating penetration in most European countries [11]. Though tax exemptions and investment subsidies are introduced, still solar thermal energy utilization in the Nordic countries is quite low, with $436.6 \mathrm{MW}_{\text {th }}$ in Denmark, 312.2 $\mathrm{MW}_{\text {th }}$ in Sweden, 30.9 $\mathrm{MW}_{\text {th }}$ in Finland, and $13 \mathrm{MW}_{\text {th }}$ in Norway in operation as of 2011 [8]. In terms of collector type, $74 \%$ of the installations in Nordic countries are glazed flat plate, while $17 \%$ are covered by unglazed flat plate, and $9 \%$ by tubular collectors. Cost competitiveness with alternative technologies, low solar intensity, and low public awareness are perceived to slow down the market penetration in the Nordic countries. Within the Nordic countries, where solar intensity is comparably similar, the solar thermal share in Norway is quite insignificant. This is mainly due to cheap hydro power availability in past decades [6]. However, an annual energy saving equivalent to 752 tonnes of oil energy and a reduction in emissions of 2.3 $\mathrm{MtCO}_{2}$ are estimated benefits of the installed solar thermal collectors and are key aspirations for large-scale integration. As of 2012, the ten largest solar thermal plants in Europe are located in Denmark, the maximum being $33,300 \mathrm{~m}^{2}$. The high taxes on fossil fuels, tax exemptions for solar heating plants, deregulated electricity market, and large-scale solar thermal system cost competitiveness are perceived to further increase the market penetration in Denmark and Nordic countries at large in the years to come [8]. In Denmark and Sweden, few large-scale solar thermal systems are connected to a district heating network [8]. The Swedish government currently has a solar thermal supporting scheme for those who want to invest in solar thermal systems and offers $0.27 € / \mathrm{kWh}$ or $18 € / \mathrm{m}^{2}$ subsidy [12]. The annual solar yield of large solar thermal systems is about 200 to $300 \mathrm{kWh} / \mathrm{m}^{2}$, and the typical installation cost is reported to be in the range of 400 to $500 € / \mathrm{m}^{2}$ [12].

With this in mind, deployment of energy efficiency measures in all sectors could reduce electricity consumption significantly and would have a vital role in load management and increased green electricity availability. With these results, a high cut in emissions and a substantial financial return from the electricity market could be plausible. Of course, Norwegian domestic customers experience a higher electricity price in dry seasons when hydroelectric production is lower. As a means to reduce the share of electricity in the heating sector and promote energy efficiency and flexibility in the energy mix, the Norwegian government put funding and a support program in place in 2008 through Enova (national public institution for promoting energy efficiency, green energy production, and solar and bioenergy utilization in Norway) [13]. The scheme is intended to cover $20 \%$ of the total investment cost up to a maximum of $10,000 \mathrm{NOK}$ (Norwegian Kroner) or $\$ 1,700$ for residential energy saving projects, like solar heating, pellet boilers, and heat pumps, as an incentive. However, low solar energy potential, relatively low electricity price, and high capital costs are challenges for the implementation of SWH in Norway.

While detailed technoeconomic, market penetration and life cycle environmental impact assessment of SWHs in the United Kingdom [14, 15], Spain [9], Greece [16, 17], a typical 
TABLE 1: Inland energy use by sector in 2009 (TWh) [6].

\begin{tabular}{lccccc}
\hline Source & Household & Service & Industry & Transport & Total \\
\hline Biomass & 1.04 & 0.23 & 0.45 & & 1.72 \\
Fossil fuel & 0.18 & 0.17 & 0.34 & 5.06 & 5.75 \\
Electricity & 2.97 & 2.11 & 1.47 & & 6.55 \\
Emission $\left(\mathrm{MtCO}_{2}\right)$ & & 0.47 & & 1.1 & 1.57 \\
\hline
\end{tabular}

city in northern cloudy climate (St. Petersburg) [18], and Cyprus [19] were available, we could not find one single work on technoeconomic performance assessments of SWHs in Norway.

With a large floor area, households in Inland Norway are the highest energy consumers in the country. This paper therefore deals with the viability and use of solar water heating for residential properties in Inland Norway and the contribution to electric energy reductions as a result of possible solar heating penetration. The paper is organized in 7 sections. The first section provides background information about current energy efficiency status and challenges. Section 2 briefly discusses the method used and presents tools used for the analysis based on structure, purpose, and function. Section 3 briefly describes Inland's existing energy system by sector, household, service, and transport. Section 4 discusses technological aspects of solar water heaters, performance, and application. Section 5 presents a solar potential assessment in Inland based on observation and satellitederived data and details of SWH system performance and an economic assessment to point out solar water heating viability, energy, and cost savings in Inland Norway. In Section 6, the value and extent of using SWH for electricity saving and imbalance enhancement in the existing Inland energy system are discussed, followed by conclusions in Section 7.

\section{Method}

Solar potential assessment and variability were studied for four stations available with ground measured (observation) solar radiation data in Inland Norway. Satellite-derived solar radiations from three different external sources were compared with ground-measured data so as to draw the representative solar potential and logical conclusions regarding the variability of solar radiation between Inland Norway and the capital Oslo. Based on Inland (in this paper wherever stated Inland refers to Inland Norway of Oppland and Hedmark counties) solar potential, hourly performance, and financial simulation for two types of solar water heaters (tubular and flat-plate) with electric auxiliary heating were analyzed for a typical annual hot water energy demand and load profile using the system advisor model (SAM) to estimate the maximum possible solar fraction (percentage of base energy demand delivered by SWH), energy saving, and economic viability. SAM is a tool used to simulate hourly solar collector performance and make economic assessments. SAM is a performance and financial model for renewable energy power systems. The model has been developed and provided by the US National Renewable Energy Laboratory (NREL) [20]. It has been used to model and simulate solar water heating [21], concentrating solar power (CSP), solar PV, wind, and geothermal power projects [20, 22]. Finally, the two types of SWH technoeconomic performance in light of Inland's solar potential were compared, and the extent of SWH penetration in the existing energy system and associated electricity savings were demonstrated and discussed.

\section{Inland Energy Use}

Inland Norway comprises two counties: Oppland and Hedmark in the east of Norway with a total number of inhabitants of 374,359 and $52,590 \mathrm{~km}^{2}$ land area [6]. The population density in urban settlements is 982 per $\mathrm{km}^{2}$, which is less than the national average of 1,633 per $\mathrm{km}^{2}$ in urban settlements, making Inland rich in biomass resource [23]. The average number of occupants in single households is 2.5 , and $60 \%$ live in detached dwellings [6]. Household energy consumption is the highest in the country with $26.6 \mathrm{MWh}$ [6], due to the fact that individual houses in Inland have larger floor areas, and the external air temperature is relatively colder in winter.

As shown in Table 1, electricity is the most highly used commodity in every sector and also serves as the main primary energy supply for heating. The share of electric energy in total energy use in the household, service, and industry sectors is $71 \%, 84 \%$, and $65 \%$, respectively. Considering the figures in the national statistics report, $65 \%$ of electric energy use for heating and $18.5 \%$ heat pump penetration in household sector, most households in Inland use direct electric heaters and electric boilers for hot water and space heating.

Hydropower is the only source of power supply in Inland with a total installed capacity of $2075 \mathrm{MW}$ ( $985 \mathrm{MW}$ with storage and $1090 \mathrm{MW}$ run-of-river) and annual generation of $9.28 \mathrm{TWh}$, as of 2009. Though no electricity import and export balance was found, the excess exportable electricity production is $2.73 \mathrm{TWh}$, and it is assumed that the system imports electricity during low precipitation periods. Biomass and oil utilization are modest, mainly used for heating in industries and households. Of the total oil demand, $88 \%$ is used by the Inland transport sector, which is considered to be the main source of emissions in the region, with a $70 \%$ share of total $\mathrm{CO}_{2}$ emissions. Solar energy use in Inland is unknown, as statistical data is not available. This might be due to its insignificant amount or nonexistence in the region. 


\section{Solar Water Heaters (SWHs)}

Other than solar photovoltaic (PV), the most popular and economical mode of solar energy utilization seems to be solar water heating. Few system components and low investment and operation costs make $\mathrm{SWH}$ suitable for low-temperature applications, that is, below $80^{\circ} \mathrm{C}[24,25]$. Basically, there are two types of SWHs: active (with pump) and passive (without pump). In cold countries like Norway, where freezing in the system components is a problem, active SWH is usually recommended. The latter is used in warm weather conditions. A typical active solar water heater consists of a collector, storage tank, pump, heat exchanger, and auxiliary heating system. The working fluid might be pure water, glycol, or other fluid with high specific heat capacity. The most commonly used solar collectors are glazed flat plate and evacuated tube (tubular) collectors. Of the SWHs in operation around the world at the end of 2011, 62\% were tubular and $28 \%$ were of the glazed flat plate type [8]. A detailed SWH system description and working principle can be found here [26]. The collector efficiency depends on a number of parameters: system configuration, optical properties (absorber, insulation, back cover plate, etc.), working fluid, supply temperature, total radiation, and ambient air temperature are some to mention. This was shown in [27], a review of various experimental and theoretical studies of flat plate and tubular SWH systems. For example, a tubular collector working on water as a working fluid and outlet temperature $32^{\circ} \mathrm{C}$ has collector efficiency of about $59 \%$, while flat plate with same working fluid and outlet temperature of $38^{\circ} \mathrm{C}$ has attained $52 \%$. However, in general, the average annual system efficiency for a welldesigned glazed flat plate collector ranges between 35\% and $45 \%$ while that of tubular collectors is between $45 \%$ and $50 \%$ [28]. Flat plate collectors perform better in high ambient temperature areas, as the back heat loss from collectors decreases as the ambient temperature increases, while the loss is higher at a low ambient temperature [28]. As opposed to flat plate collectors, where the back heat loss is higher during low ambient temperature, evacuated tube collectors perform better, as the vacuum serves as insulation and retains the captured solar energy in low ambient temperature conditions. This was illustrated by outdoor testing in northern maritime climate [29].

\section{Residential Solar Water Heating for Inland}

In areas where solar intensity is strong and the share of fossil fuel in primary energy supply is substantial, solar energy has significant bilateral use as a means of energy saving (heating and electrification) and a clean development mechanism (CDM) [29-31]. Due to low solar radiation availability and an extended winter period, solar energy has only been used in Norway for heating purposes as a complement to electric heating, with very little penetration [32]. In a solar heat worldwide report from 2011, solar thermal installation in Norway was estimated at $13 \mathrm{MW}_{\text {th }}$ (83\% glazed flat plate, $11 \%$ unglazed flat plate, and $6 \%$ tubular collectors) [8]. Solar collectors of $168 \mathrm{~m}^{2}$ for Norway's first passive standard building in Bergen and $95 \mathrm{~m}^{2}$ for the Bjørnveien building in Oslo, which cover $20-25 \%$ of the heat demand, are known as large-scale SHW installations in Norway [32]. The market potential for solar thermal systems in Norway is estimated to be between 5 and 25 TWh by 2030 [32]. The considerable gap in estimation is due to future cost uncertainty in conventional energy sources and competitive alternative technologies, while the passive house standard and Enova's support schemes are expected to boost Norway's solar thermal market. More than nine companies have been active in the solar thermal market since 1995, manufacturing, distributing, and installing solar thermal systems. There is no known statistical data regarding solar thermal use in Inland from Statistics Norway, but, based on solar potential assessments, considerable solar energy yield would be possible. Considering Statistics Norway's survey data, Inland energy consumption per household is the highest of all counties in Norway. Hence, as an alternative energy mix and to reduce high-value electricity consumption for heating, solar water heating might be the best solution if it is viable. As of 2011, more than $50 \%$ of dwellings in Norway are detached houses, occupied by $60 \%$ of the total number of inhabitants with an average floor area of $112 \mathrm{~m}^{2}$ and 2.5 persons per households [6]. With this consideration for Inland's population, at least $50 \%$ of dwellings are suitable for deployment of typical (4 to $6 \mathrm{~m}^{2}$ and $300 \mathrm{~L}$ daily hot water demand) roof-top solar water heaters.

5.1. Inland Solar Potential. Solar energy is the cleanest source of energy and does not contribute to global warming. Depending on the location on the earth's surface and sunearth relative motion, solar radiation striking the earth's surface continuously varies. The monthly average daily global solar radiation in Norway is modest compared to tropical regions and varies between 0.1 and $0.35 \mathrm{kWh} / \mathrm{m}^{2}$ during the coldest month, January, and between 4 and $5.5 \mathrm{kWh} / \mathrm{m}^{2}$ during the peak summer, July, as shown in Figure 1. The annual average daily global solar radiation in Norway is $2.46 \mathrm{kWh} / \mathrm{m}^{2}$ [32]. Solar intensity is relatively strong in the eastern (mostly Inland) (Inland and Oslo located in Figure 1 show only their relative location, and this does not indicate actual location) and southern parts of Norway. Duffie and Bechman [33] suggest that, for a maximum annual solar energy collection in a given location, the surface inclination angle should be equal to the latitude angle. Whereas, for a maximum summer (April to November) collection, the surface inclination should be 10 to $15^{\circ}$ less than the latitude angle, and for winter (December to March) it is found to be 10 to $15^{\circ}$ more than the latitude angle.

Annual hourly measured global solar radiation data were obtained only for three populous locations in Inland and the capital Oslo from eklima [34], a web portal for free access to the Norwegian Metrology Institute's database for the years 2005 to 2009 . The four sites considered were Østre Toten $\left(60.7^{\circ} \mathrm{N}, 10.87^{\circ} \mathrm{E}, 264 \mathrm{~m}\right)$, Øystre Slidre $\left(61.12^{\circ} \mathrm{N}, 9.06^{\circ} \mathrm{E}\right.$, $521 \mathrm{~m})$, Rinksaker $\left(60.77^{\circ} \mathrm{N}, 10.8^{\circ} \mathrm{E}, 264 \mathrm{~m}\right)$, and Oslo $\left(59.9^{\circ} \mathrm{N}\right.$, $\left.10.72^{\circ} \mathrm{E}, 94 \mathrm{~m}\right)$. The ultimate goal and intention of the solar potential assessment is to estimate hourly performance of solar water heaters in Inland using SAM. However, SAM 


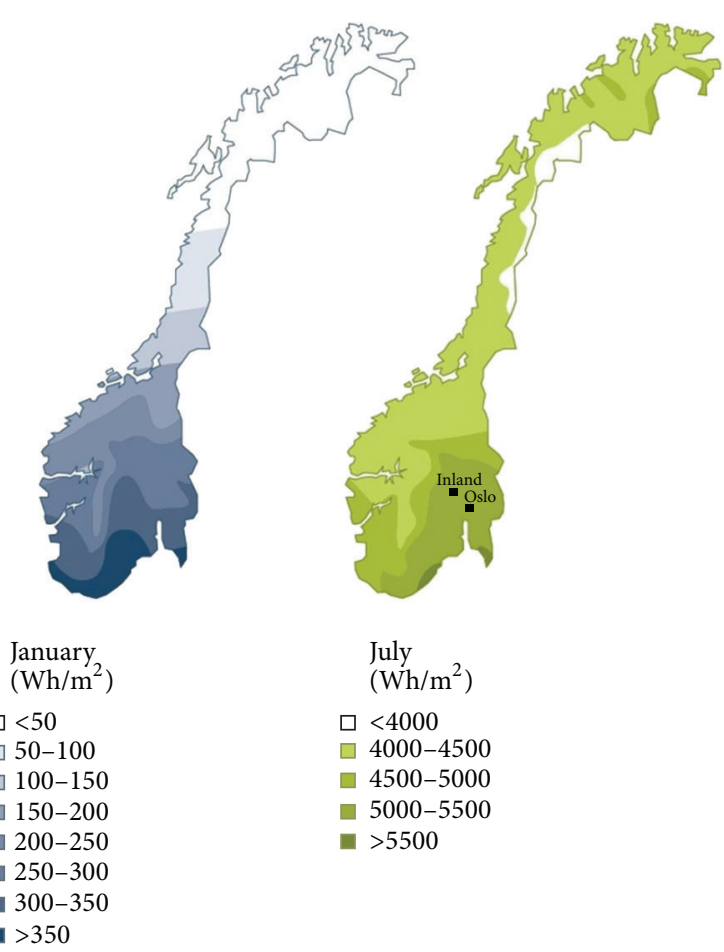

FIGURE 1: Monthly average daily global solar radiation map of Norway for the months of January and July [Wh/ $\mathrm{m}^{2} /$ day] [32].

uses hourly beam and diffuse radiation as input variables for the simulation, and it was difficult to find these hourly observation data in Norway, as the stations record only global radiation. Therefore, as shown in Figure 2, the consideration is to compare the long-term variation in monthly global solar radiation (observation) between Oslo and Inland (average of the three sites in Inland) and to use Oslo's hourly beam and diffuse radiations (satellite-derived) for SWH simulation in Inland with some correction factor. Oslo is not part of Inland Norway, but it is the only site close to Inland and available with free hourly beam and diffuse radiation (satellite-derived) in Norway.

NASA's surface meteorology, IWEC (International Weather for Energy Calculations), and meteonorm's weather database sites are the most common sources of hourly and monthly solar radiation data for more than 2,100 locations with an 18-year (1986-2005) average [35-37]. The Norwegian Meteorological Institute uses a Kipp and Zonen CM11 pyranometer in all stations to record global solar radiation, which is according to the World Meteorological Organization's guidelines [38].

As shown in Figure 2, considerable variations exist between observation and satellite-derived data (satellitederived data used here is the average of three sources NASA, IWEC, and meteonorm). However, despite the longitudinal variation, global solar radiation and annual distribution at all sites for both sources of data seem to be attuned, and the deviance range is also insignificant. Root mean square error (RMSE) computed for hourly average annual global radiation

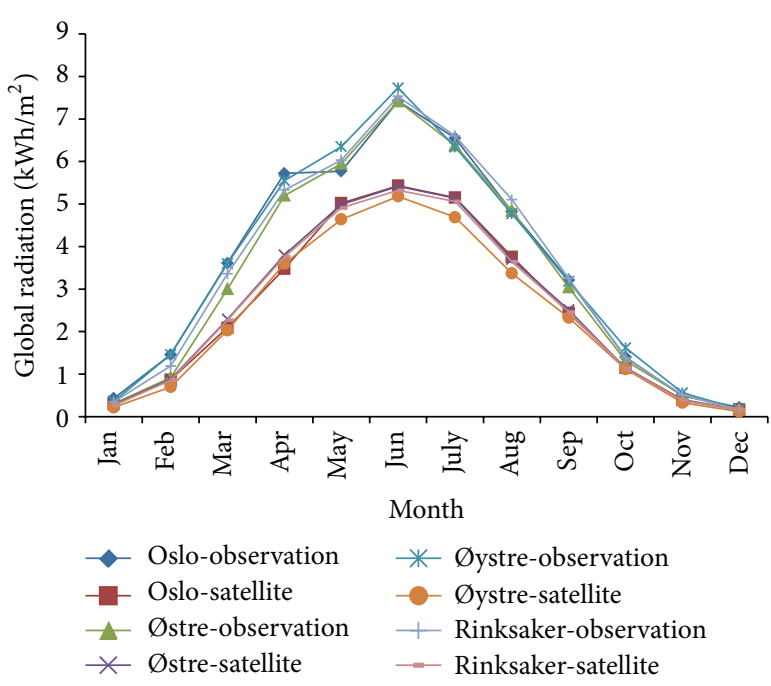

FIGURE 2: Monthly average observation and satellite-derived daily global solar radiation $\left(\mathrm{kWh} / \mathrm{m}^{2}\right)$.

deviance between observation and satellite-derived data was found to range between $33 \%$ in Oslo and 38\% in Øystre.

In this case, the average of Østre, Øystre, and Rinksaker is taken as the Inland average. Hence, based on the observation data, Inland's daily global solar radiation averaged as $3.37 \mathrm{kWh} / \mathrm{m}^{2}$ while it is $2.48 \mathrm{kWh} / \mathrm{m}^{2}$ using satellitederived data, $36 \%$ lower than that of observation. At this point, it is difficult to figure out the cause of the data discrepancy between the two sources, as this is outside the scope of this paper. However, based on the literature and previous experimental studies, for standard measurement procedures, hourly average observation data is considered to be more accurate and relevant for time series performance simulations, whereas poor cosine response and reradiation from pyranometers are always susceptible sources of error in global radiation measurement (observation) [34]. However, observation values in Inland can contribute to better understanding and accurate solar potential prediction in Norway, as very few stations record hourly global radiation.

On the other hand, regardless of data source and considerable spatial variation, global daily solar radiation variation in the south-eastern part (Oslo and most of Inland) of Norway is very slight, as shown in Figure 1. The small mean error in long-term monthly global solar radiation between Oslo and Inland shown in Figure 3 could be taken as an indication of invariability. As a result, it is possible to conclude that the annual global solar potential and distribution in Inland are similar to Oslo's. With these considerations, it is reasonable and practical to use Oslo's hourly beam and diffuse radiation to estimate hourly solar collector energy yield in Inland. Had it been possible to get hourly observation data for direct and diffuse components of global radiation in Oslo, it would have been possible to estimate the solar energy yield in observation case. One might think that it is possible to 


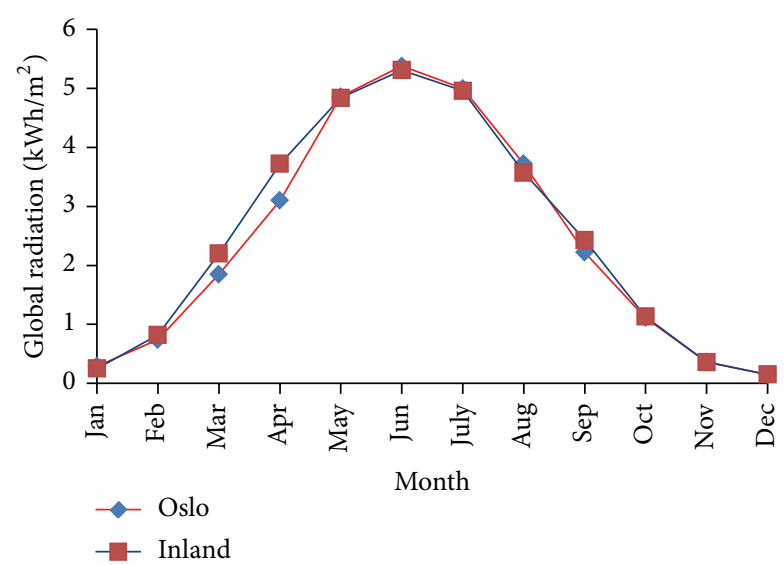

FIGURE 3: Satellite-derived monthly average daily global solar radiation for Oslo and Inland.

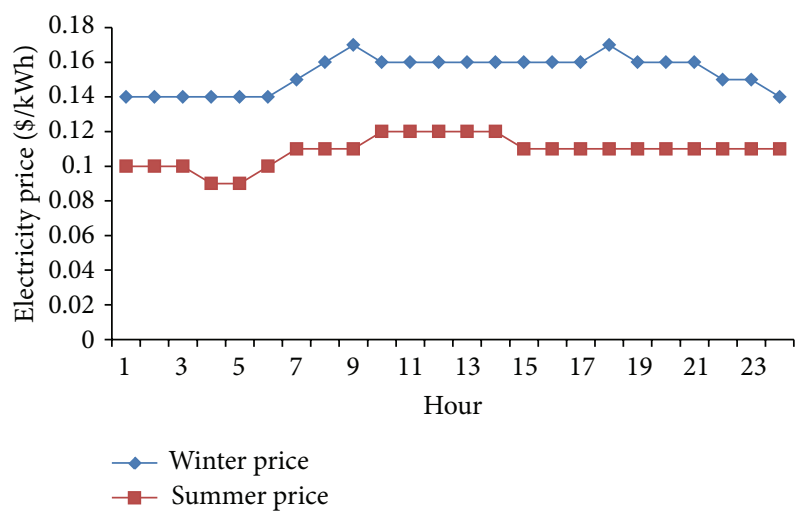

FIGURE 4: Seasonal hourly electricity price for household (including all fees) [39].

normalize the satellite-derived hourly data over observation, which is true if it is on a horizontal surface, but there is no systematic correlation between diffuse and beam components to estimate total radiation on inclined collector surfaces.

5.2. Model Input Parameters. In addition to solar radiation, electricity price and hot water usage are the main input parameters. As part of the Nord Pool electricity market, the electricity price in Norway is determined by water availability in reservoirs. In the model, the seasonal hourly electricity price is used, as shown in Figure 4. Usually, electricity in summer (from May to September) is cheaper than in winter (from October to April), due to sufficient water supply being available in hydropower dams during summer. The electricity price also varied on a yearly basis. Normally, the Nord Pool electricity market cycled over a single "leap" year (7 years), three wet years, three normal years, and one dry year, where a high electricity price in dry years and a low price in wet years cycled. Since 2010 was a dry year with high electricity prices, 2011 and 2012 were taken as wet years and the average is used for this case study.
TABLE 2: Collector parameters.

\begin{tabular}{lcc}
\hline Parameters & $\begin{array}{c}\text { AE50 glazed } \\
\text { flat }\end{array}$ & $\begin{array}{c}\text { SR30 } \\
\text { tubular }\end{array}$ \\
\hline $\begin{array}{l}\text { Gross area }\left(\mathrm{m}^{2}\right) \\
\begin{array}{l}\text { Heat gain coefficient } \\
\text { Fr } \tau \alpha)\end{array}\end{array}$ & 4.66 & 4.67 \\
$\begin{array}{l}\text { Heat loss coefficient } \\
\text { (FrUL) }\end{array}$ & 0.691 & 0.419 \\
$\begin{array}{l}\text { Incidence angle modifier } \\
\text { (IAM) coefficient }\end{array}$ & 3.4 & 1.5 \\
\hline
\end{tabular}

Water heating energy demand in Norwegian households ranges between 2.5 and $5 \mathrm{MWh}$ [2]. Considering the average $3.75 \mathrm{MWh}$, equivalent daily hot water demand at $45^{\circ} \mathrm{C}$ was estimated to be $250 \mathrm{~L}$ using SAM. Hot water storage temperature is assumed to be $45^{\circ} \mathrm{C}$. The hourly hot water demand distribution profile is adopted from an extensive field measurement study in the UK [40]. The measurements were made in 120 dwellings. For our case study, the normalized average hourly load profile was adopted merely to serve as a model for Inland Norway. In this work, two types of solar water heating models were considered, namely, glazed flat plate and tubular collectors. Two models with the same system components and different collector specifications with series of collector areas from the SAM database were chosen: alternate energy AE glazed flat plate collector 2.6, $3.7,4.66$, and $5.18 \mathrm{~m}^{2}$ and suntask SR tubular collector 1.59 , $2.32,3.07$, and $4.67 \mathrm{~m}^{2}$. The collector specification for $4.67 \mathrm{~m}^{2}$ is shown in Table 2 and is based on the Solar Rating and Certification Corporation's (SRCC) performance rating [41]. The models are chosen based on gross collector area for rooftop installation. The SAM solar water heater model works on a two-tank system, main and auxiliary tank. We assume storage tank capacity to be $250 \mathrm{~L}$ and auxiliary heater capacity to be $4.5 \mathrm{~kW}$ for our case study. We assume an electric water heater energy factor (overall heating efficiency) of $90 \%$. The circulation pump power consumption is $40 \mathrm{~W}$ for both solar loop and storage loop and is regarded as a loss. The storage is assumed to be placed inside a room where the mean ambient air temperature is $20^{\circ} \mathrm{C}$. SAM considers the storage tank as a two-node stratified tank to estimate the heat loss. The optimal collector tilt (the handbook of photovoltaic science and engineering [42, p. 942] suggests a linear approximation to estimate the optimal tilt angle at a given location as $3.7+0.69 * \varnothing$, where $\varnothing$ is the latitude angle $\left.\left(^{\circ}\right)\right)\left(45^{\circ}\right)$ in the northern hemisphere and heat exchanger efficiency (85\%) are optimistically assumed values. Solar radiation transmittance in transverse direction for tubular collectors are accounted in SAM by an incidence angle modifier. The working fluid in the solar collector loop is assumed to be glycol ( $\mathrm{Cp}=$ $3.4 \mathrm{~kJ} / \mathrm{kg}-{ }^{\circ} \mathrm{C}$ ). SAM uses the annual and monthly average ambient temperature to estimate the sinusoidal hourly mains (cold water) temperature [43].

Investment costs from two sources for each type of collectors were considered for demonstration based on previously studied SWH projects from RET (RET screen is clean energy project analysis tool) Screen International's project 


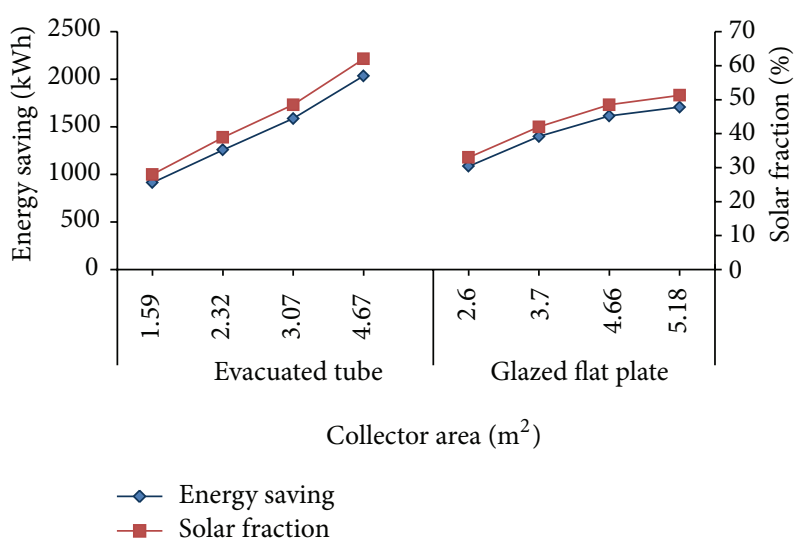

FIgURE 5: Annual auxiliary energy saving and solar fraction for each type of collectors.

database [44] at 593 and $680 \$ / \mathrm{m}^{2}$ for flat plate and tubular, respectively. The Norwegian Energy and Water Resource Directorate's (NVE) (detailed investment cost analysis based on actual price from suppliers for hydropower, wind power, district heating, and solar water heating was done by NVE in 2011 [45]) SWH cost summary report is the other source, where the figures are estimated to be 700 and $850 \$ / \mathrm{m}^{2}$ for flat plate and tubular collectors, respectively. A fixed annual operation and maintenance cost of $\$ 30$ is also assumed. Economic parameters considered for the financial analysis were $3 \%$ inflation rate, $6 \%$ discount rate, $5 \%$ electricity price escalation rate, and 25 years project life time. The investment is assumed to be self-financed without loan.

5.3. System Performance and Viability. Solar fraction is a parameter used to show the contribution of SWH in annual energy demand, expressed as a percentage. 100\% means all demand supplied by SWH, while $0 \%$ means that all demand is met by the auxiliary electric heater. With this understanding, based on typical household annual water heating energy demand $5 \mathrm{MWh}$, hourly simulation result showed that tubular collectors have better solar fraction and energy saving than flat plate collector for the series of collector areas shown in Figure 5. Tubular collectors' SWH system response in energy saving and solar fraction for collector area is steeper, while that of flat plates tends to be flatter. This is due to the fact that tubular collectors have better efficiency in cloudy and low-temperature areas. In fact, theoretically flat plate collectors show higher efficiency during the summer season when the ambient temperature and solar radiation are high, but in a country like Norway, where the annual solar intensity and ambient temperature are reasonably low, convective and conductive back heat loss from flat plate collectors is quite high as opposed to tubular collector, where the vacuum retains the useful heat gain. The monthly energy saving results shown in Figure 6 for the typical collector gross area $4.66 \mathrm{~m}^{2}$ revealed that tubular collectors save significant amounts of electric energy during the summer, from April to September, where the solar intensity is relatively strong with better extended day time availability (longer sunshine hours).

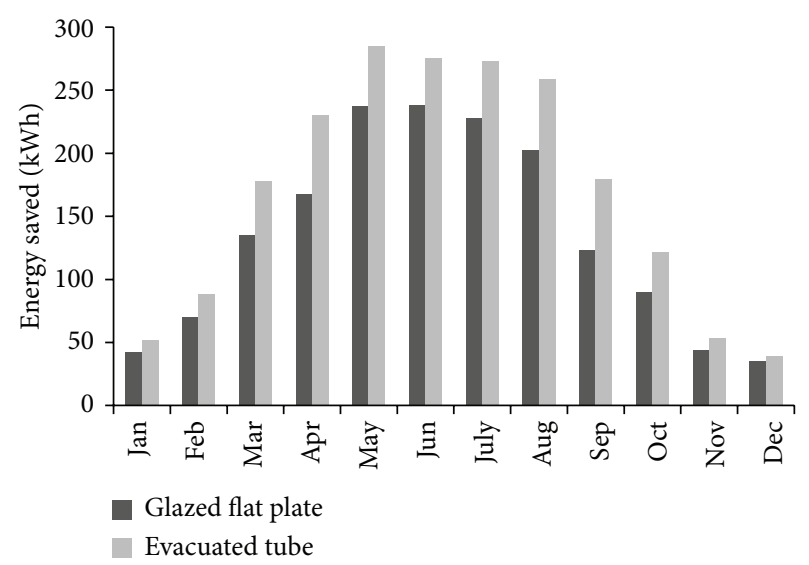

FIGURE 6: Monthly auxiliary (electric) energy saving for $4.66 \mathrm{~m}^{2}$ collector area for each type of collectors.

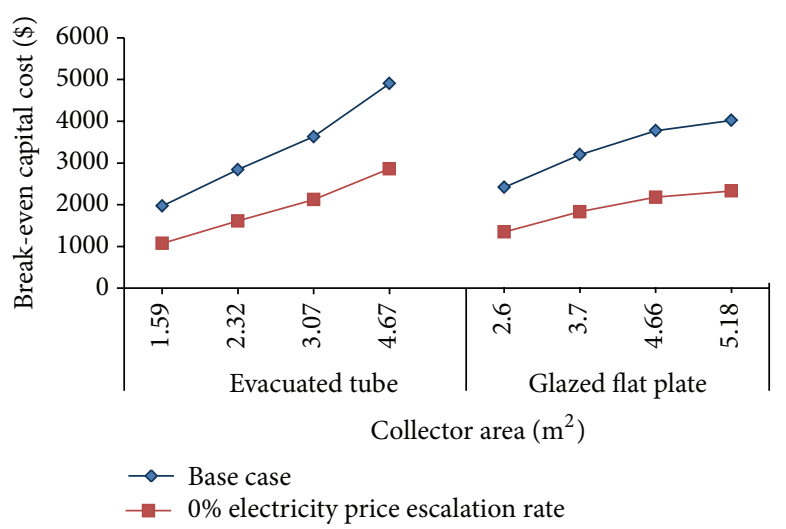

FIGURE 7: Break-even capital cost sensitivity for electricity price.

In technoeconomic assessments, the choice between energy saving solutions should be based on comparative life cycle cost (LCC) [21, 46]. Break-even occurs when the LCC of electric bill saving offsets the LCC of SWH. Break-even is therefore a "no-profit and no-loss" point and is expressed in years over the project's life time. The fewer the years to break-even, the more attractive the SWH solution and the higher the cost saving over the project's life time. Net present value (NPV) is total cost saving over the project life time, and it is zero at break-even point. With these understandings, it is worth estimating that the investment cost frontier is equivalent to zero NPV, and this cost is referred to as the break-even cost in this paper. This is done in SAM by continuously changing the investment cost until the NPV comes to zero for each case. All SWH investment costs below break-even cost would be viable. Break-even cost generally increases with collector area for both collector types, as shown in Figure 7, but as with energy saving, it is steeper in the case of tubular collectors. Using a larger size for the same annual demand would increase energy saving and profitability. For example, in the case of the $4.66 \mathrm{~m}^{2}$ tubular collector, investment costs below $\$ 4,903$ are viable, and the system cost below this would be higher in terms 
TABLE 3: Annual energy savings and economic attributes.

\begin{tabular}{|c|c|c|c|c|}
\hline \multirow{2}{*}{ Output parameters } & \multicolumn{2}{|c|}{ Base case-no incentive } & \multicolumn{2}{|c|}{ Scenario case- $20 \%$ incentive } \\
\hline & Flat plate & Tubular & Flat plate & Tubular \\
\hline Solar fraction (\%) & 48 & 62 & 48 & 62 \\
\hline Energy saving (kWh) & 1614 & 2035 & 1614 & 2035 \\
\hline Net present value (\$) & 512 & 914 & 1164 & 1707 \\
\hline Payback period (year) & 11.51 & 11 & 9.9 & 9.46 \\
\hline IRR (\%) & 7.26 & 7.85 & 9.31 & 10 \\
\hline
\end{tabular}

of profitability or high NPV, whereas for similar collector areas flat plate collectors' break-even cost is estimated at $\$ 3,774$, meaning that, to achieve the same energy saving bill, the $4.66 \mathrm{~m}^{2}$ flat plate collector's investment cost should be $\$ 1,129$ lower than that of the $4.66 \mathrm{~m}^{2}$ tubular collector. A showing case for comparison using the investment cost from NVE is used to demonstrate technoeconomic attributes, as shown in Table 3 . The higher cost range of NVE, $850 \$ / \mathrm{m}^{2}$ for tubular and $700 \$ / \mathrm{m}^{2}$ for flat plate, was compared with the break-even cost of the $4.66 \mathrm{~m}^{2}$ collector area. From Figure 7 , the break-even cost for tubular and flat plate is found to be $1,049 \$ / \mathrm{m}^{2}$ and $809 \$ / \mathrm{m}^{2}$, respectively. This implies that, based on NVE investment cost estimation, both systems are viable. In either case, deployment of typical SWH could give a substantial reduction in the amount of electric energy, as shown in Table 3. Tubular collectors would be more economic and applicable with better energy saving in terms of both net present value (NPV) and payback period. Moreover, SWH investment is sensitive to initial investment cost; considering the Norwegian government's 20\% investment cost subsidy as an incentive for SWH deployment, it was shown that NPV increases by $127 \%$ for flat plate and by $86 \%$ for tubular collectors with shorter payback period. Hence, increasing the subsidy would reduce risk as regards investment return, strengthen public trust, and motivate more people to use SWH.

As Figure 5 depicted, for a given solar fraction or energy saving, one can draw a horizontal line that intersects with both curves and observe that tubular collectors could supply the required energy at reduced collector area. Coupled with this, despite the high investment cost in the case of tubular collectors, both types of collectors have comparably similar payback periods as shown in Table 3. Meaning that the energy saving and hence operation cost saving were high enough to pay back the investment cost as low as that of flat plate collectors. Similarly comparing the break-even capital cost for increased collector area, tubular collectors have higher break-even cost than flat plate collectors as shown in Figure 7. For example, to acquire the same break-even capital cost of $\$ 3,000$, the flat plate collector area should be $46 \%$ higher than that of tubular collector, which corresponds to $2.32 \mathrm{~m}^{2}$ for tubular and $3.4 \mathrm{~m}^{2}$ for flat plate as shown in Figure 7.

Internal rate of return (IRR) is the discount rate which gives zero NPV. In essence, a project is viable if IRR is greater than the discount rate used, and a project with high IRR is always a priority. With this understanding, IRR for the base case (no incentive) is estimated as $7.85 \%$ for tubular collector as shown in Table 3 and increases to $10 \%$ for $20 \%$ state investment cost subsidy. This showed that, apart from short payback period and high NPV, the subsidy substantially increases the IRR of the investment. It is apparent that subsidizing SWH investment cost aims to promote and boost the SWH market in such a way as to decrease the market price and make it self-sustained.

From direct emission reduction perspectives, tubular collectors contribution is more than flat plate collectors, as it is proportional to the electricity saving. However, a life cycle environmental impact assessment study based on the UK perspectives revealed that flat plate collectors have marginal benefits (7\%) over tubular collectors [15]. This is due to the fact that tubular collectors manufacturing process is energy intensive $\left(77.7 \mathrm{MJ} / \mathrm{m}^{2}\right)$ as compared to flat plate collectors $\left(4.18 \mathrm{MJ} / \mathrm{m}^{2}\right)$, but in a region like Inland where the source of electricity is $100 \%$ renewable, it is reasonable to assume that the life cycle environmental impact of tubular collector is lower than that of flat plate.

5.4. Sensitivity Analysis. It is worth testing the system for sensitivity of susceptible financial and technical parameters. But it is apparent from the technical analysis that in a given location the solar fraction would increase if either hot water usage at low temperature increases or hot water demand decreases. In this case, the measured solar potential from eklima (see Section 4) is higher than that used in this study. Hence, the solar fraction in the case in question would obviously increase. It is very important to consider the SWH investment cost for electricity price sensitivity, so as to determine the size of investment return. The base case assumption was $5 \%$ electricity escalation rate, which is a reasonably low limit of historical electricity price escalation rates in Norway. Over the last decade, electricity prices in Norway have increased by an average of $8 \%$ [6] and are expected to continue to increase despite various speculations regarding future electricity prices forecast as a consequence of the quota scheme additional green electricity charge [3]. Break-even cost is highly sensitive to electricity price variation. As shown in Figure 7 , in a $0 \%$ escalation rate scenario, there is considerable variation with that of the base case and increases with collector area. This is due to the fact that most of the costs associated with electric energy saving are the future cost components, which are therefore more affected by the electricity price. A high electricity price favors SWH deployment and vice versa. 


\section{Discussion}

It is clear from the technoeconomic assessment of tubular and glazed flat plate collectors in Inland's specific case that tubular collectors are more advantageous from an economic point of view than flat plates. But it should be noted that, for other locations, the result might be different as it depends largely on solar resource availability and ambient air temperature. The existing energy system's electricity saving for integration of solar heating system in Inland is worth estimating. For the typical $4.66 \mathrm{~m}^{2}$ tubular collector roof-top installation, it was possible to reduce the electric energy used in a single household by up to $2 \mathrm{MWh}$. In this case, assuming deployment of typical tubular solar water heating systems in all detached dwellings ( $60 \%$ of dwellings)m with 2.5 occupants in each dwelling for a total of 374,359 inhabitants in Inland, the total annual electric energy saving would be $182 \mathrm{GWh}$. This is equivalent to a reduction of 15,690 tonnes of oil energy and $48.6 \mathrm{ktCO}_{2}$ emissions [8]. With this, deployment of SWHs in Inland could increase the share of renewables in primary energy supply, reduce high value electric energy from existing electricity-intensive heating systems, and make a substantial contribution to global emission reduction.

The results show that significant electricity savings would be possible as a result of distributed small-scale economic energy conservation measures, for example, solar water heaters. Further, moderate solar potential, SWH large-scale installation profitability [31], and on-ground energy policy are key motivators for deploying of large-scale solar thermal systems in Inland. A demonstration case of the Taiwanese government's incentive program for deployment of SWHs, which ran in two packages, 1986-1991 and 20002004, resulted in tremendous socioeconomic development, through energy saving, market development, and job opportunities [47]. In countries like Norway, where solar thermal experience is almost nonexistent, apart from the targeted grant and tax incentives, promotional tools would make a substantial contribution to solar thermal market penetration, until the market becomes self-governing. Most G-20 countries have been using grant and/or tax incentives as a promotional tool for renewable-based heat production, including solar thermal [9]. With this result, in Spain lowtemperature solar thermal installation increased by $330 \%$ for the period 1999-2008 and declined by $40 \%$ after the economic crises in Europe in 2008. In terms of viability, Inland's low population density is considered to be the main challenge when it comes to connecting households with large-scale district heating systems. But it is plausible to supply households from small-scale district heating systems here and there, whereby solar thermal could have a significant share, as in other Nordic countries with comparable solar potential, that is, Denmark, Sweden, and Finland [8].

Homeowners usually focus on investment cost, not operating costs, and they want to be paid back in the shortest time possible for any investment they make. Hence, increasing the subsidy not only reduces investment cost but also shortens the payback period and increases future cost savings, and the SWH solution would be more attractive, whereas the prosperous life in Scandinavian countries and the "able to pay" financial freedom for high electricity prices are perceived by the author to be the major barrier to SWH diffusion in Norway. Electric heaters are easy to use and have a less complicated system and better aesthetic value than SWHs. In this case, the subsidy alone might not be as efficient as desired for SWH diffusion in the community as a whole, beyond small target groups. But it has massive implications for behavioural change.

Extrinsic and intrinsic motivations are important behavioural tools for changing public awareness towards use of SWH. People are extrinsically motivated for the sake of achievement or winning in competition with others and intrinsically for personal enjoyment and comfort [2]. Once motivation has been created in groups of SWH users through subsidy, it will not end up with them; rather, the displayed SWHs induce extrinsic motivation in nearby neighbors and diffuse through the community as a whole. A demonstration case for high penetration in the Toyota Prius hybrid car's market in the USA is a good example of SWH promotion $[2,48]$. Despite the fact that many high-performance hybrids cars are available on the market, the Toyota Prius was designed in such a way as to preach and reflect one's environmental awareness easily. As a result, people were extrinsically motivated to buy a Toyota Prius and show that they cared for environment. Households who do not have SWH on their roof-top might feel that they are not eco-friendly and are extrinsically motivated to install SWH. This in turn increases market volume and ultimately the SWH market becomes self-sustained with high penetration.

\section{Conclusion}

With modest solar radiation availability, solar water heating with auxiliary electric heating for residential application is found to be viable in Inland. Generally speaking, for a given energy demand in Inland, tubular collectors are better than flat plates in terms of performance and cost. Moreover, within a tubular SWH system, for the same energy demand larger collector sizes are better, as long as enough space is available for installation. As discussed in Section 5.1, solar radiation in southern and south-eastern Norway is comparably stronger than Inland and would result in better solar fraction than Inland. A government subsidy package for deployment of SWH as a complement to existing electric-intensive heating systems would boost the benefit and stretch the market for large-scale solar thermal installation. Further integration of SWHs in line with the government policy for bioenergy and heat pumps penetration for domestic and industrial application in Norway could increase the share of renewables in the primary energy supply and create flexibility in the energy mix at national level. In doing so, strategic advocacy towards energy efficiency in society would build adaptability and trust for SWH penetration in the region and ultimately long-term behavioral change in society towards use of SWH could be envisioned. Lastly, it would be interesting to validate the simulation results through outdoor testing or field measurement, and the authors recommend this as future work. 


\section{Conflict of Interests}

The authors declare that there is no conflict of interests regarding the publication of this paper.

\section{Acknowledgment}

The authors would like to thank the National Renewable Energy Laboratory (NREL) for providing them with SAM software free of charge.

\section{References}

[1] European commision, Europe 2020 targets, http://ec.europa.eu/ atoz_en.htm.

[2] I. H. Magnussen, B. Bergesen, H. G. Lisa, and B. Langseth, "Household energy consumption," Tech. Rep., Norwegian Water Resources and Energy Directorate, 2012.

[3] H. L. Raadal, E. Dotzauer, O. J. Hanssen, and H. P. Kildal, “The interaction between electricity disclosure and tradable green certificates," Energy Policy, vol. 42, pp. 419-428, 2012.

[4] International Energy Agency (IEA), "Nordic energy technology perspective-pathways to a carbon neutral energy future," Tech. Rep., International Energy Agency (IEA), Paris, France, 2013.

[5] Stastistics Norway, "Energy statistics 2000," Tech. Rep., Stastistics Norway, 2002.

[6] Statistics Norway, 2013, http://www.ssb.no/en/energi-og-industri.

[7] NVE, http://www.nve.no/no/Energil/Fornybar-energi/Vannk$\mathrm{raft} /$.

[8] F. Mauthner and W. Weiss, "Solar heat worldwide-markets and contribution to the energy supply 2011," Tech. Rep., AEEInstitute for Sustainable Technologies, Gleisdorf, Austria, 2013.

[9] M. P. Pablo-Romero, A. Sánchez-Braza, and M. Pérez, "Incentives to promote solar thermal energy in Spain," Renewable and Sustainable Energy Reviews, vol. 22, pp. 198-208, 2013.

[10] ESTIF, "Solar thermal markets in Europe: trends and market statistics, 2010," Tech. Rep., European Solar Thermal Industry Federation (ESTIF), 2011.

[11] J. M. Cansino, M. P. Pablo-Romero, R. Romn, and R. Yiguez, "Taxes incentives to promote res deployment: the Eu- 27 case," in Sustainable Growth and Applications in Renewable Energy, InTech, 2011.

[12] NEGEST, "Report on technical investigations of large solar thermal systems (wp2.d5)," Tech. Rep., New Generation of Solar Thermal Systems (NEGST), 2007.

[13] Enova, http://www.enova.no/finansiering/privat/tilskuddsordningen/solfanger/135/0/.

[14] S. R. Allen, G. P. Hammond, H. A. Harajli, M. C. McManus, and A. B. Winnett, "Integrated appraisal of a solar hot water system," Energy, vol. 35, no. 3, pp. 1351-1362, 2010.

[15] B. Greening and A. Azapagic, "Domestic solar thermal water heating: a sustainable option for the UK?" Renewable Energy, vol. 63, pp. 23-36, 2014.

[16] C. J. Koroneos and E. A. Nanaki, "Life cycle environmental impact assessment of a solar water heater," Journal of Cleaner Production, vol. 37, pp. 154-161, 2012.

[17] G. Tsilingiridis and G. Martinopoulos, "Thirty years of domestic solar hot water systems use in Greece: energy and environmental benefits: future perspectives," Renewable Energy, vol. 35, no. 2, pp. 490-497, 2010.
[18] J. G. Rogers, M. C. McManus, and S. J. G. Cooper, "Potential for reliance on solar water heating throughout the summer in northern cloudy climates," Energy and Buildings, vol. 66, pp. 128-135, 2013.

[19] S. Kalogirou, "Thermal performance, economic and environmental life cycle analysis of thermosiphon solar water heaters," Solar Energy, vol. 83, no. 1, pp. 39-48, 2009.

[20] NREL, System Advisor Model (SAM), 2013, http://www.nordpoolspot.com/.

[21] H. Cassard, P. Denholm, and S. Ong, "Technical and economic performance of residential solar water heating in the United States," Renewable and Sustainable Energy Reviews, vol. 15, no. 8, pp. 3789-3800, 2011.

[22] X. Wang, L. Kurdgelashvili, J. Byrne, and A. Barnett, “The value of module efficiency in lowering the levelized cost of energy of photovoltaic systems," Renewable and Sustainable Energy Reviews, vol. 15, no. 9, pp. 4248-4254, 2011.

[23] E. Trømborg, T. F. Bolkesjø, and B. Solberg, "Impacts of policy means for increased use of forest-based bioenergy in Norwaya spatial partial equilibrium analysis," Energy Policy, vol. 35, no. 12, pp. 5980-5990, 2007.

[24] L. M. Ayompe, A. Duffy, S. J. McCormack, and M. Conlon, "Validated TRNSYS model for forced circulation solar water heating systems with flat plate and heat pipe evacuated tube collectors," Applied Thermal Engineering, vol. 31, no. 8-9, pp. 1536-1542, 2011.

[25] W. Xiaowu and H. Ben, "Exergy analysis of domestic-scale solar water heaters," Renewable and Sustainable Energy Reviews, vol. 9, no. 6, pp. 638-645, 2005.

[26] U.S. Department of Energy (DOE), "Solar water heaters," 2012, http://energy.gov/energysaver/articles/solar-water-heaters.

[27] R. Shukla, K. Sumathy, P. Erickson, and J. Gong, "Recent advances in the solar water heating systems: a review," Renewable and Sustainable Energy Reviews, vol. 19, pp. 173-190, 2013.

[28] DGS, Planning and Installing Solar Thermal Systems: A Guide for Installers, Architects, The German Solar Energy Society (DGS), James and James, 2005.

[29] M. Srinivas, "Domestic solar hot water systems: developments, evaluations and essentials for "viability" with a special reference to India," Renewable and Sustainable Energy Reviews, vol. 15, no. 8, pp. 3850-3861, 2011.

[30] A. H. Al-Badi and M. H. Albadi, "Domestic solar water heating system in Oman: current status and future prospects," Renewable and Sustainable Energy Reviews, vol. 16, no. 8, pp. 5727-5731, 2012.

[31] A. Gastli and Y. Charabi, "Solar water heating initiative in Oman energy saving and carbon credits," Renewable and Sustainable Energy Reviews, vol. 15, no. 4, pp. 1851-1856, 2011.

[32] L. Bjorhovde Rindal and F. Salvesen, "Solar energy for heating purposes," Tech. Rep. 1503-0318, Norwagian Water Resource and Energy Directorate (NVE), Oslo, Norway, 2008.

[33] J. A. Duffie and W. A. Bechman, Solar Enginengine of Thermal Processes, John Wiley \& Sons, 1980.

[34] F. Vignola, P. Harlan, R. Perez, and M. Kmiecik, "Analysis of satellite derived beam and global solar radiation data," Solar Energy, vol. 81, no. 6, pp. 768-772, 2007.

[35] Meteonorm, "Global metrological database," 2012, http://meteonorm.com/.

[36] NASA, "NASA Surface meteorology," 2008, https://eosweb.larc .nasa.gov/sse/RETScreen/. 
[37] U.S Department of Energy. International database for energy calculation, 2012, http://energy.gov/node/773661/energy\%20 plus/cfm/weatherdata.cfm.

[38] L. Hagen, Measured, modelled and satellite derived solar radiation in scandinavia [M.S. thesis], Geophysical institute, University of Bergen, 2011.

[39] Nord pool spot, 2012, https://sam.nrel.gov/.

[40] Energy Saving Trust, "Measurement of domestic hot water consumption in dwellings," Tech. Rep., Energy Saving Trust, London, UK, 2008.

[41] Solar Rating and Certification Corporation (SRCC), http:// www.solar-rating.org/index.html.

[42] A. Luque and S. Hegedus, Eds., Handbook of Photovoltaic Science and Engineering, John Wiley \& Sons, Chichester, UK, 2003.

[43] J. Burch and C. Christensen, "Towards development of an algorithm for mains water temperature," in Solar 2007: Sustainable Energy Puts America to Work, Including 36th ASES Annual Conference, Proceedings of the 32nd National Passive Solar Conference and 2nd Renewable Energy Policy and Marketing Conference, pp. 173-178, American Solar Energy Society (ASES), Cleveland, Ohio, USA, July 2007.

[44] RET Screen International, http://www.retscreen.net/ang/home .php.

[45] B. Fladen, K. E. Stensby, and S. K. Mindeberg, "Cost of production of power and heat," Tech. Rep. 978-82-410-0750-7, Norwagian Water Resource and Energy Directorate (NVE), Oslo, Norway, 2011.

[46] D. Assefa, Techno-economic assessment of parabolic trough steam generation for hospital [M.S. thesis], KTH, School of Industrial Engineering and Management (ITM), Energy Technology, 2011.

[47] K. Chang, T. Lee, and K. Chung, "Solar water heaters in Taiwan," Renewable Energy, vol. 31, no. 9, pp. 1299-1308, 2006.

[48] S. E. Sexton and A. L. Sexton, "Conspicuous conservation: the prius halo and willingness to pay for environmental bona fides," in Conspicuous Conservation, University of California-Center for Energy and Enviromental Economics, 2011. 


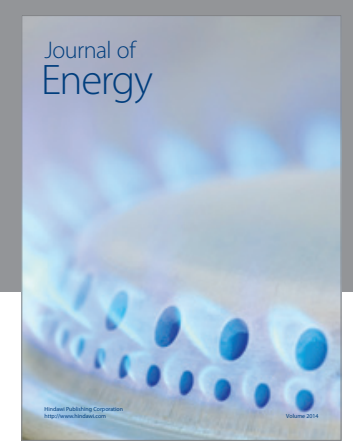

Journal of

Industrial Engineering
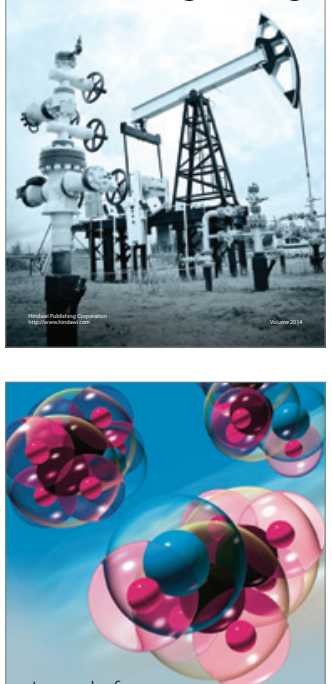

Fuels
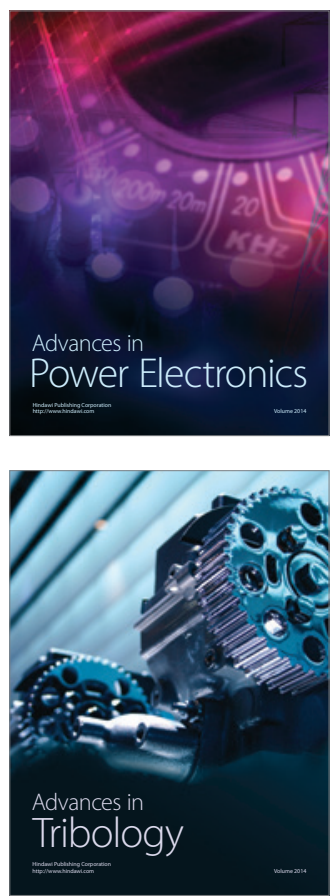

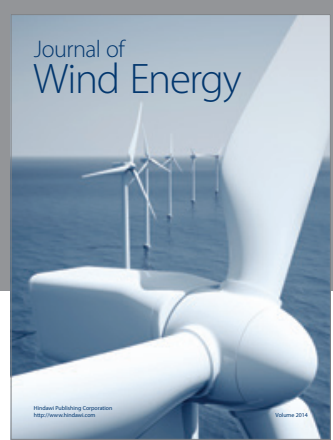

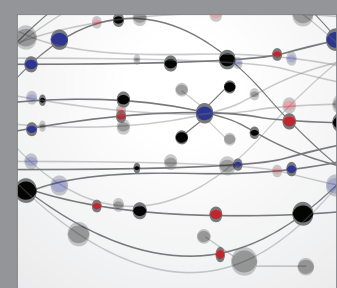

The Scientific World Journal

Submit your manuscripts at http://www.hindawi.com

Journal of

Structures
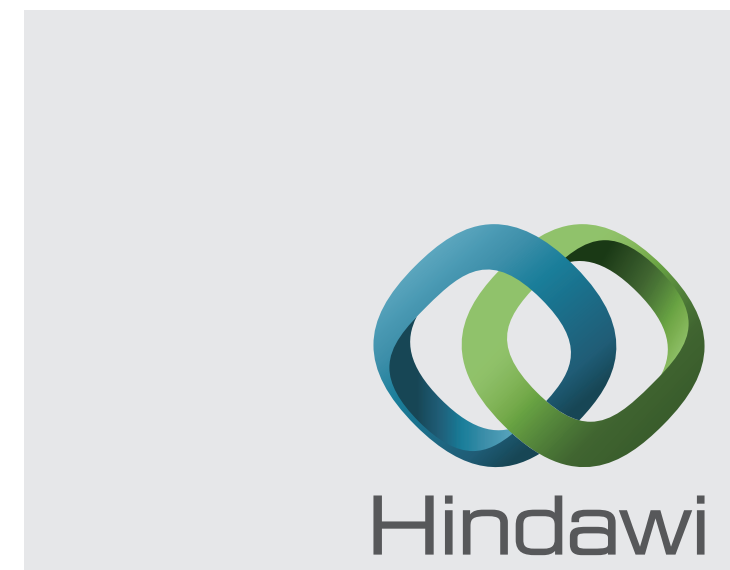

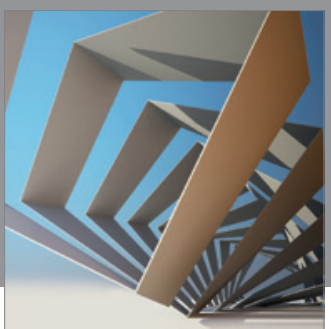

Rotating

Machinery
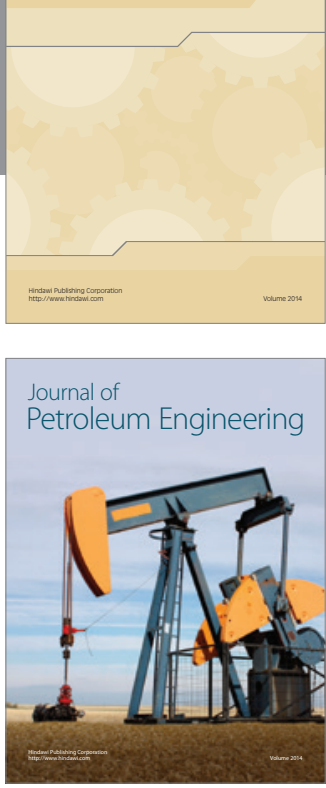

Journal of

Solar Energy
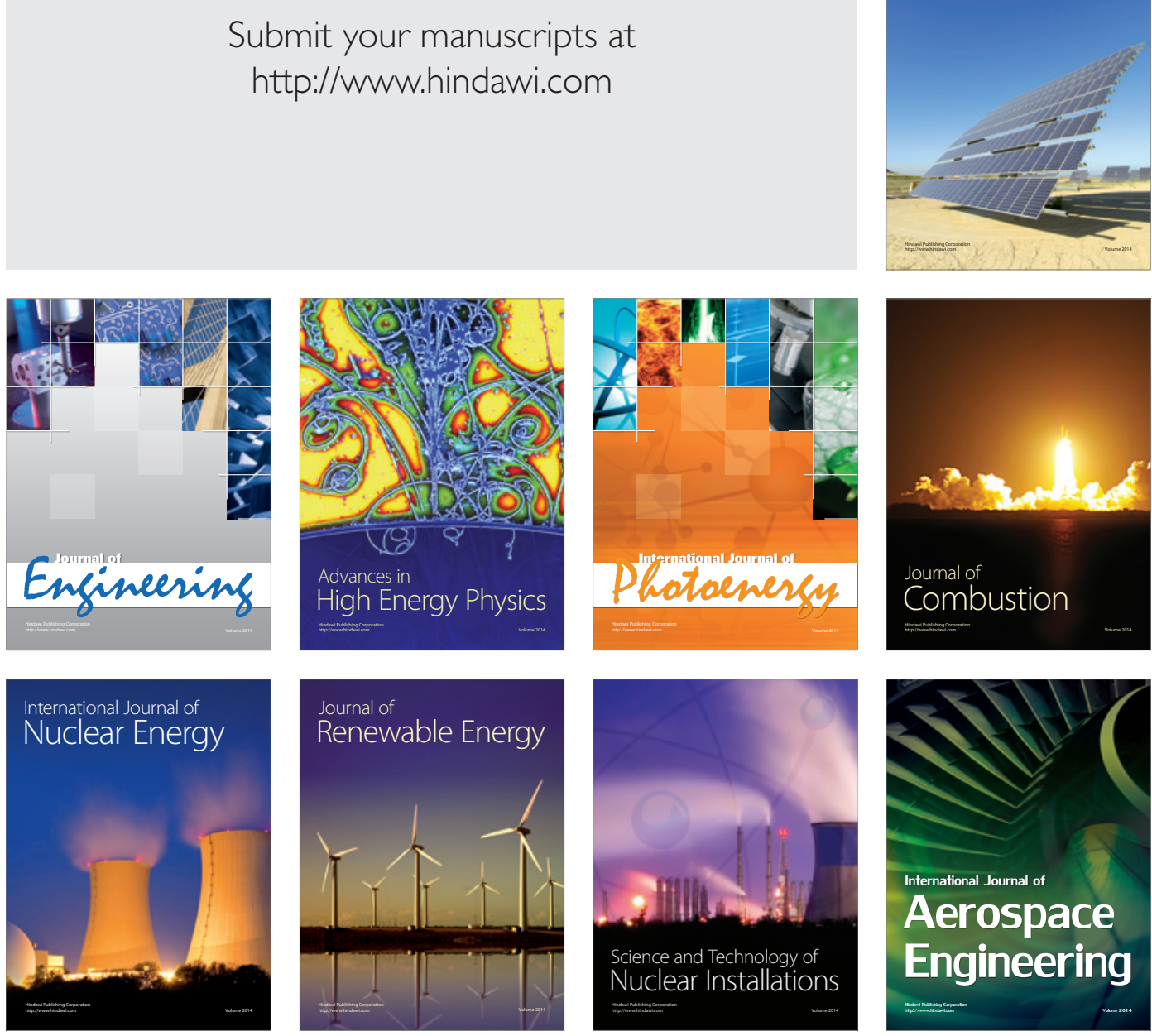